\title{
産業連関表を用いた水産基盤整備の費用対効果算出 に関する一考察
}

\author{
古屋温美* - 岡 貞 行** 中 村 \\ 森 義和 $* * * *$. 芝井穣 $* * * * *$ - 長 野
}

隆***

章******

\begin{abstract}
漁村においては市町村合併など新たな動きのなかで, より一層の水産業と地域の振興に寄与する水産基盤整備の実施が求 められている. 本研究は, 市町村合併に伴う地域振興施策や, 新たな産業の立地や漁業の効率化を促進する水産基盤整備な どの実施による効果を算出するため, 漁村の産業構造を反映した産業連関表の作成を行った. 次に施策の実施により生じる 将来の産業構造や就業構造の変化と, 地域の水産業（ここでは生産から流通・加工・消費までの一連のシステムとする）に 将来おこりうる変化を想定し，その変化がもたらす地域経済波及効果の分析を，漁村の産業連関表を用いて行う方法につい て提案した.
\end{abstract}

\section{1. はじめに}

沿岸の漁村では市町村合併や漁協合併協議が進んでお り, 合併効果を生むような水産業や漁村の振興施策が必 要とされ, また, 漁業生産と漁村の維持のため, 新たな 水産関連産業や観光業など地域の産業振興と施策の実施 が重要な課題となっている.

このような漁村を取巻く要請のもと, 地域の水産業(こ こでは生産から流通・加工・消費までの一連のシステム) が合併によってどう変化するか, 新たな産業の立地, 設 備投資や技術革新, 公共事業の実施など施策の実施に よって, 将来の産業構造の変化を予測し, 水産業など特 定産業が地域経済に与える影響や経済波及効果を算出す るため, 地域の産業構造と経済波及構造を表す産業連関 表を作成した。

本研究では, (1)北海道における複数の産業連関表につ いて, 各漁業部門の産業構造と経済波及構造を比較し, 水産業の課題を整理する。

次に北海道南茅部町を事例として, (2)水産業の地域へ の経済波及効果について, 他産業との経済的関連性を定 量的に把握し, 同町の産業連関表を作成し, 産業構造上 の問題点を分析する. 更に, (3)その問題点を解決し地域 内の経済効果が増加する対策として, 水産基盤整備の実 施による産業構造の変化を産業連関表で表し（対策後の 産業連関表を作成), 対策実施前の産業連関表との比較に よる効果の分析手法について検討する.

\section{2. 漁業部門に関する産業連関表上の問題点}

\section{（1）漁村の産業構造と産業連関表}

産業連関表は，一定の地域（国や県など）において，

\begin{tabular}{|c|c|c|}
\hline * 正会員 & 工 博 & (有)マリンプランニング＼cjkstart代表取締役 \\
\hline${ }^{* *}$ 正会員 & & 長崎県水産部水産基盤計画課 課長 \\
\hline$* * *$ & & 水産庁漁港漁場整備部防災漁村課 災害査定官 \\
\hline **** & & $\begin{array}{l}\text { 北海道開発局函館開発建設部江差港湾事務所 } \\
\text { 事業専門官 }\end{array}$ \\
\hline$* * * * *$ & & 北海道南茅部町水産林商課 水産係長 \\
\hline ****** 正会員 & 工 博 & $\begin{array}{l}\text { 公立はこだて未来大学教授 情報アーキテク } \\
\text { チャ学科 }\end{array}$ \\
\hline
\end{tabular}

1 年間に行われた財やサービスの産業間の取引を一覧表 にまとめたものである．列方向には製品の買い手として の産業部門が，行方向には製品の売り手としての産業部 門がそれぞれ表示され，各産業間の取引関係を示してお り, 次の 3 つの部分で構成される.中間投入（=中間需 要）部門は，商品を生産するために用いられた中間財の 取引関係を示す. 粗付加価値部門は, 生産活動に必要な 労働, 資本などの費用を示す. 最終需要部門は, 消費, 投資, 移輸出などを示す.

例えば，漁業をするのに漁網やえさ，衣服など，各産 業から資材を調達したり，漁業者やその家族などへ報酬 が支払われ, 製品は流通業, 加工業等へ販売されるとい う関連である.

ここで既存の産業連関表の多くは, 都道府県や大都市 を対象に作成されており，漁村のような小地域の産業構 造を対象としたものはほとんど作られていない。そのた め，水産業の地域への経済波及効果を産業連関表を用い て分析する場合，現状では，大地域の産業連関表を活用 しているが, それには以下の問題がある.

\section{（2）既存の産業連関表から見た漁業部門の問題点}

漁村における水産業の地域への経済波及効果を既存の 産業連関表を活用して算出する場合, 漁業部門について 以下に示すような問題点がある.

(1) 漁業は, 既存の産業連関表では「漁業」という 1 産業部門で表されるが，地域の漁業と産業の経済的関連 性を再現するには漁業種類ごとに分類する必要がある。 これは, 漁業種類によって投入産出構造が異なることに よる. 同様に関連産業（水産加工業のうちコンブ加工な ど，観光業）の細分化などが必要である.

(2) 漁村地域では, 地域経済のなかで漁協事業の位置 づけが大きいが, 産業連関表上は, 表一 1 に示すように各 部門に統合されている. 事業として規模の大きい販売事 業や，購買事業などは商業の中で 1 つの部門として細分 化すべきである.

(3) 図-1に示す既存の産業連関表に関する最終需要 項目の構成比の比較から, 各産業連関表に共通して域内 
表一1 漁協の事業と産業連関表上の分類

\begin{tabular}{|c|c|c|}
\hline 漁協の事業 & 事業の概要 & 部 門 \\
\hline 信用事業 & $\begin{array}{l}\text { 組合員などから貯金などを預かり，それを } \\
\text { 原資として，組合員などに貸出を行う。. }\end{array}$ & $\begin{array}{l}\text { 金融・保険 } \\
\text { ・不動産 }\end{array}$ \\
\hline 共済事業 & $\begin{array}{l}\text { 経営や家計の安定のため, 厚生共済, 生活 } \\
\text { 総合共済, 火災共済などの事業を共済組合 } \\
\text { や共水連と共同で行う. }\end{array}$ & . \\
\hline 購買事業 & $\begin{array}{l}\text { 組合員や一般市民に対して, 漁船用燃料油, } \\
\text { 漁業用資材, 日用品のような生活物資など } \\
\text { の受入と供給を行う事業. 組合は手数料収 } \\
\text { 入を得る. }\end{array}$ & 商業 \\
\hline 販売事業 & $\begin{array}{l}\text { 活魚・鮮魚・水産加工品の受託販売を行い, } \\
\text { 組合は手数料収入を得る. }\end{array}$ & 11 \\
\hline 利用事業 & 荷別き場での車両や魚箱の貸出を行う. & サービス業 \\
\hline 指導事業 & $\begin{array}{l}\text { 営漁, 生活改善などに関する各種講習会な } \\
\text { どの実施, 資源管理, 增殖, 漁場管理など } \\
\text { を行う. }\end{array}$ & $n$ \\
\hline $\begin{array}{l}\text { 自営事業 } \\
\text { (定置) }\end{array}$ & 組合自営の定置網漁業を行う. & 漁業 \\
\hline
\end{tabular}

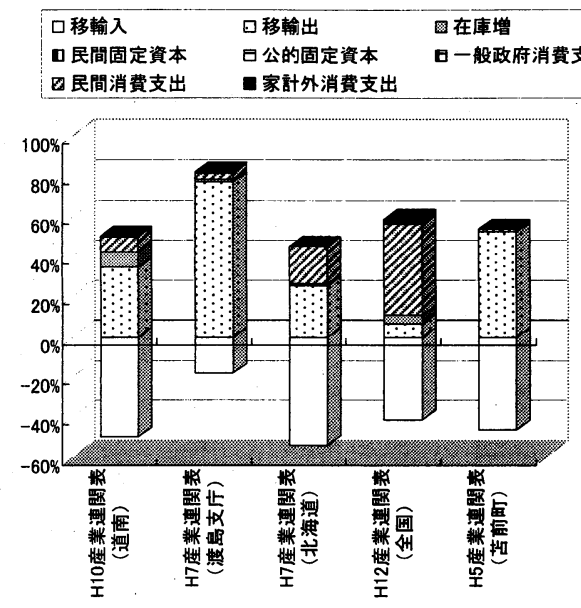

図-1 漁業の最終需要項目の構成

の消費者による民間消費支出が少なく移輸出が多い特徵 がある．また，各産業連関表で移輸入が多いが，原材料 を域外から調達する加工場などがない限り大きくならな いはずである，これは，各産業連関表が大地域（日本全 体あるいは北海道全体）の産業連関表を基本に作成され ているためと考えられる．また，この移輸入は産業連関 表の作成過程では, 実績値の調査が困難なため, 最後に つじつまが合うように算出した数値である場合が多く, 表の数值が実態を表しているとは言い難い. 従って, 漁 村地域の産業連関表を作成する際は, 個別の産業の聞き 取りにおいて, 移輸入部分を詳細に聞き取るなど工夫が 必要である。

本研究では, 漁村の産業連関表を作成するにあたり, 既存の産業分類をそのまま用いるのではなく, 漁業部門 は地域の漁業種類に応じて細分化し, 漁協の事業や加工 業, 観光業など関連産業部門についても産業構造に合わ せて部門を細分化するなど, 既存の産業連関表の課題に
対処した.

\section{3. 漁村の産業連関表の作成（南茅部町の事例）}

\section{（1）北海道南茅部町の概要}

南茅部町は, 表一 -2 に示すように人口約 8,000 人, 15 才 以上の就業者約 4,500 人のうち半分以上 $(2,500$ 人) が漁 業に従事し, 漁業の平成 14 年の生産額は 73 億円である.

また, 製造業出荷額 45 億円 (平成 11 年) のうち食品製 造業が 43 億円で, そのほほ $100 \%$ が水産加工業である.

南茅部町の主な漁業は養殖コンブ漁業, 天然コンブ漁 業, 定置網漁業, 刺網漁業などである. 漁業者はこれら の漁業を組み合わせて, 生計を立てている.

\section{（2）漁村の産業連関表の作成}

南茅部町を対象として, 南茅部町産業連関表 (平成 10 年) を, 既存の道南地域の産業連関表 (平成 10 年 北海 道内地域間産業連関表 (道南)) を用いて作成した。

南茅部町の産業構造を特徵付ける養殖コンブ漁業, 天 然コンブ漁業, 定置網漁業, 刺網漁業などの 4 つの漁業, 漁業協同組合の事業, 加工業，観光業など関連産業に関 する原材料の購入金額, 人件費や減価償却費などの経費, 製品の販売額などの経済波及量と製品の販売先である波 及経路を, 経営収支資料と現地七アリングから求め, そ れ以外の産業については南茅部町に無い産業を除いて, 道南地域の経済波及経路抢よび波及構成と同じとした。

ヒアリング対象者は表一 3 に示す町内の平均的な漁家 や加工場・宿泊施設を選択した。漁業 4 種については 5 件の漁家に, 水産加工業は加工場と仲買を営む 1 事業所, 漁協, 旅館宿泊は各 1 事業所にヒアリングを実施した。

ヒアリング対象者を上記のように選定した理由は, 養 殖コンブ漁業と天然コンブ漁業の両漁業を営む漁家が一 般的であり，かつ支出する経費の項目や比率は同じで, 水揚げしたコンブはほとんどが組合の受託販売となるこ とから, 水揚げ額の平均的な漁家 2 件の経済波及構造を

表-2 南茅部町の概要

\begin{tabular}{|c|c|c|}
\hline 標 & 年度 & \\
\hline ㅁ & H 12 & 7,935 人 \\
\hline 15 才以上就業者数 & H 7 & 4,517 人 \\
\hline うち漁業(構成比) & H 7 & 2,471 人 $(54.7 \%)$ \\
\hline 漁業生産量 & H 14 & 32 千トン \\
\hline 漁業生産額 & H 14 & 73 億円 \\
\hline うち養殖コンプ漁業 & $\mathrm{H} 14$ & 25 億円 \\
\hline うち天然コンブ漁業 & H 14 & 16 億円 \\
\hline うち定置網漁業 & H 14 & 19 億円 \\
\hline うち刺網漁業など & H 14 & 13 億円 \\
\hline 農業粗生産額 & H 11 & 2 百万円 \\
\hline 製造業出荷額 & H 11 & 45 億円 \\
\hline うち食品製造 (構成比) & H 11 & 43 億円 (95.6\%) \\
\hline
\end{tabular}


表一－ヒアリング対象者

\begin{tabular}{|c|c|}
\hline 業 種 & ヒアリング対象者 \\
\hline 養殖コンブ漁業 & \multirow{2}{*}{ 養殖コンブ漁家 2 件 } \\
\hline 天然コンブ漁業 & \\
\hline 刺網漁業など & 刺網漁家 2 件 \\
\hline 定置網漁業 & 定置漁家 1 件 \\
\hline 水産加工業 & 水産加工場と仲買をかねる 1 事業所 \\
\hline 漁協 & 漁協 1 件 \\
\hline 旅館宿泊 & 1 事業所 \\
\hline
\end{tabular}

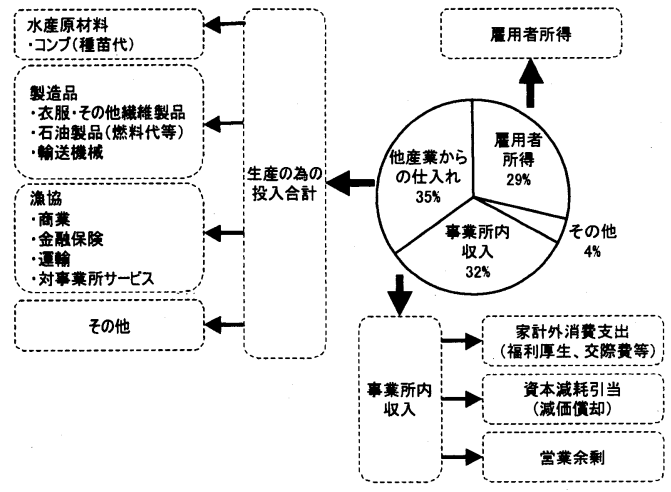

図-2 養殖コンブ漁業の生産構造のイメージ

代表させて利用した，定置網漁業，刺網漁業などについ ても水揚げ額の平均的な漁家を対象として選択してい る.

水産加工業と旅館宿泊は，町内の経営規模の大きな事 業所とし,できるだけ仕入先, 販売先などが具体的かつ, 多岐にわたり，投入産出構造が明らかになるようにした。 また，ヒアリングにおいては製品を生産するために用 いられた中間財の取引関係と, 生産活動に必要な労働, 資本など生産構造の内訳，そして生産された製品が町内 外のどの産業に金額でいくら販売されたかという経済波 及経路および波及構成を各対象者毎に聞き取りを行っ た.

図一2 は養殖コンブ漁業の生産構造のイメージを示し ている．他産業からの仕入，雇用者への賃金の支払い， 事業所内での収入が生産構造の内訳となっている.

\section{4. 南茅部町における産業構造上の問題点}

作成した南茅部町産業連関表から，南茅部町の産業構 造の再現性および漁業，加工業，観光業など細分化した 産業のうち漁業の投入構造，中間需要並びに最終需要か らみた，産業構造上の問題点を分析した。

\section{（1） 漁業部門の投入構造}

図一 3 は，南茅部町の漁業 4 種と比較のため道南地域 の産業連関表の漁業部門について，内生部門，粗付加価 值部門け投入係数を図示したものである。

南茅部町の各漁業は，道南地域の漁業部門と比較して

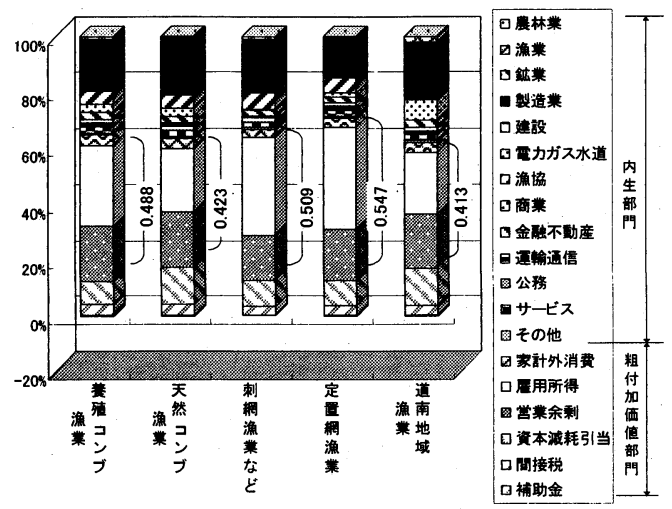

図一3 漁業部門の内生部門及び粗付加価値部門の投入係数 の比較

内生部門への投入が小さく，逆に粗付加価値部門が多く なっている．粗付加価値のうち，特に雇用所得と営業余 剰の合計は，図に示すように道南全体が 0.413 であるの に対し，南茅部町は $0.423 \sim 0.547$ と大きく，中でも定置 網漁業 $(0.547)$ は水揚額の約 6 割が雇用者所得と親方の 収入である。

各漁業ともに製造業への投入が多く，漁業毎に特徴が ある. 養殖コンブ漁業はコンブ乾燥作業のボイラー燃料 の費用が，天然コンブ漁業は漁船の購入・修繥等の輸送 機械の費用がかかる. 刺網漁業などはえ繩漁業と兼業し ている場合が多く，漁業部門や水産加工部門から餌を購 入している.

定置網漁業では，網の購入・使用量が多く繊維工業品 の購入が大きい。

\section{（2）中間需要（他産業の原材料）の比較}

图-4には漁業部門の中間需要の比較を示す.

南茅部町の養殖コンブ漁業を除くすべての漁業で生産 物の $100 \%$ 弱が製造業（水産加工業）へ産出されている.

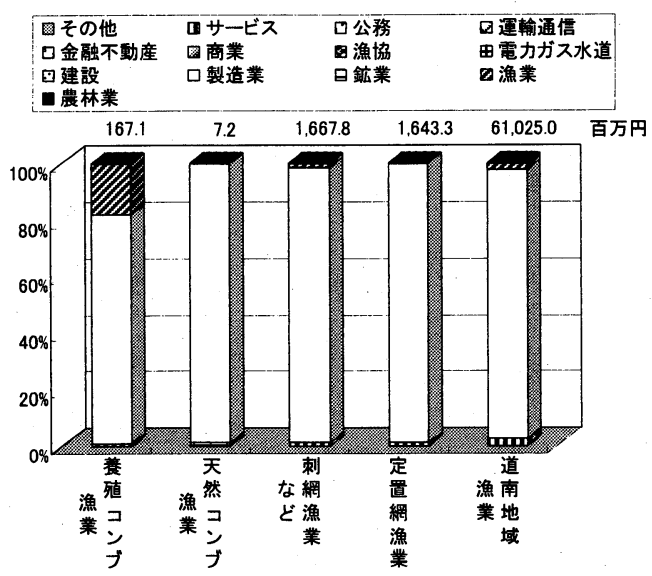

図-4 漁業部門の中間需要の比較 


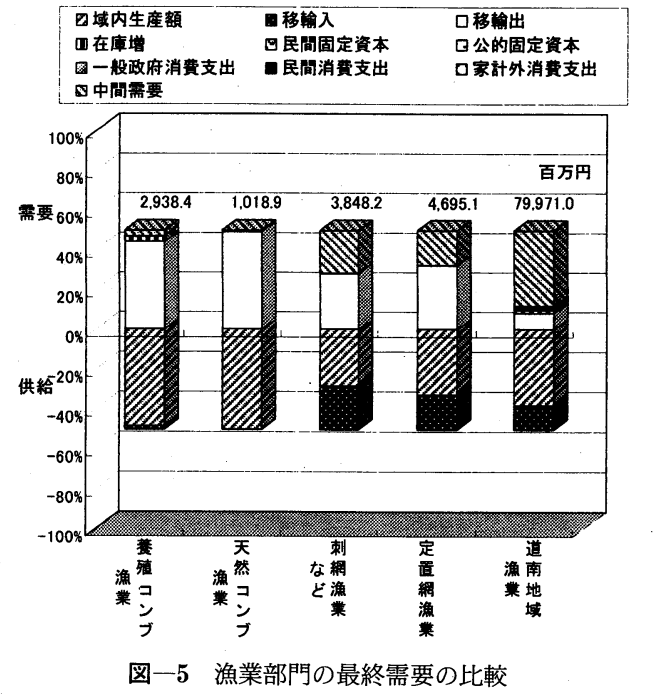

養殖コンブ漁業が製品を漁業部門へ産出しているの は，責殖に使うコンブ種苗供給分である。

各漁業において町内のサービス業（飲食業など）での 消費がほとんど 0 に近く, 地産地消が進んでいないこと がわかる。

\section{(3) 最終需要の比較}

図一5 は漁業部門の最終需要を比較したものである。

南茅部町の養殖コンブ漁業と天然コンブ漁業は, 中間 需要も域内最終需要も小さく, また移輸入も小さいこと から，域内で生産されたほとんどのコンブが加工もされ ず，移輸出されていることがわかる.

定置漁業, 刺網漁業などは, 中間需要がそれぞれ半分 以下で，移輸出がそれぞれ過半を占めており，他産業の 原材料として使用されるより,移輸出されるほうが多い.

道南全体では, 中間需要が $2 / 3$ を占めていることから, 加工業等他産業で多く使用されている。

\section{5. 問題解決のための施策の実施}

以上から, 南茅部町では水産物は町内での流通, 消費 が少なく, そのまま町外へ移出されるなど漁業の産業構 造の特徵が明らかになった。これは産業構造上の問題点 であり，施策によって改善することができる。このよう に地域の産業連関表を作ることによって, 地域の産業構 造上の問題点を知り, 問題点を解決するための対策を実 施することができる。

また，現状の産業構造が把握できるので，ぞの部分の 構造を変えて, 地域波及効果を大きくするか, 実施する 水産基盤整備のメニュー（加工場, 種苗センター, 冷蔵 庫など)の選択や期待する効果の予測などに利用できる.

具体的には考えられる整備メニューと漁業の仕組みの

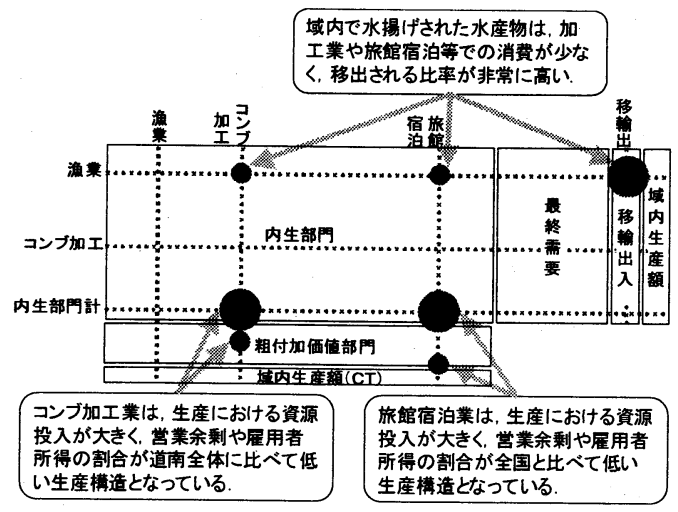

图一6 産業構造の問題点

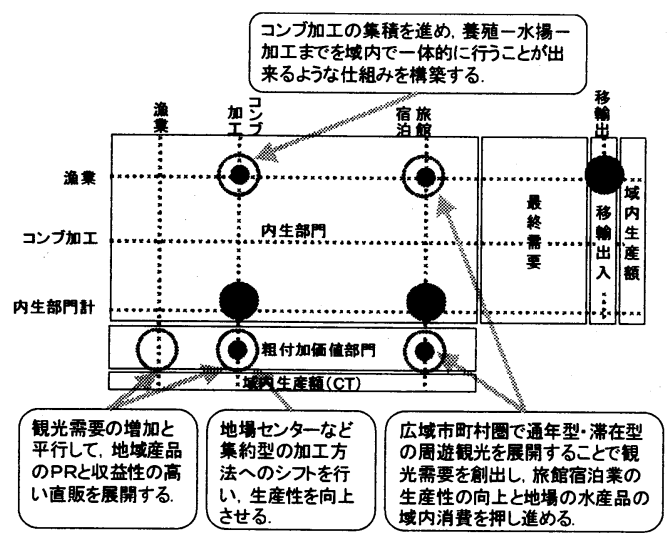

図一7 問題点に対する施策

変化について，いくつかのパターンを想定し，施策後の 産業構造の変化を推測し産業連関表に反映して最終需要 に伴う中間需要と粗付加価値を計算することにより水産 基盤整備の効果評価を行うことができる.

また産業構造を推測する場合，いろいろなシナリオが 考えられるが, そのシナリオごとに数值で効果評価でき， シナリオ選択の道具として利用できる.

これは例えば, 市町村合併後に, 公共部門の効率化に よって市民の税負担が軽減される，他部門へ投資がまわ される, 観光業との連携, 地産地消が進む, イベントを 実施する, 研究施設が集積する, 公共事業を行う, など 施策のパターンを想定し産業構造の変化を予測すること である．地域の波及効果を算出できれば，住民にとって もわかりやすい合併効果を提示することが可能である.

\section{6. 水産基盤整備による経済波及効果の分析手 法}

\section{（1）水産基盤整備による対策効果の例}

水産基盤整備を実施することで期待できる効果として は，表一4に示すように 
表一4 水産基盤整備による対策効果の例

\begin{tabular}{|c|c|c|}
\hline & 水産基盤整備に関連する施設 (例) & 効果(例) \\
\hline $\begin{array}{l}\text { (1)水産業の生産性が向 } \\
\text { 上するような対策 }\end{array}$ & $\begin{array}{l}\text { ・漁港内の蓄養施設 } \\
\text { ・集約的な加工場 (用地など) 整備 } \\
\text { ・漁業の生産性が向上するような施設(浮棧橋, クレー } \\
\text { ン, 屋根付き岸壁など) }\end{array}$ & $\begin{array}{l}\text { • 出荷調整などで, 作業性が改善される } \\
\text { • 中間投入が隇り, 粗付加価值部門の構成比率が上がる }\end{array}$ \\
\hline $\begin{array}{l}\text { (2)域内需要が向上する } \\
\text { ような対策 }\end{array}$ & ・種苗生産施設(域内向け) & ・域内で利用する種苗を生産・供給すると域内需要が増える \\
\hline $\begin{array}{l}\text { (3)域外需要増加によっ } \\
\text { て生産額の増加を図 } \\
\text { るような対策 }\end{array}$ & $\begin{array}{l}\text { - 種苗生産施設(域外向け) } \\
\text { - 漁港内の㦈殖施設 } \\
\text { - 漁港内の直販・見学施設 }\end{array}$ & $\begin{array}{l}\text { ・域外へ種苗を販売する } \\
\text { 㦈殖による生産額増加 } \\
\text { ・購入者, 見学者などの増加で関連産業の生産額が増加する }\end{array}$ \\
\hline
\end{tabular}

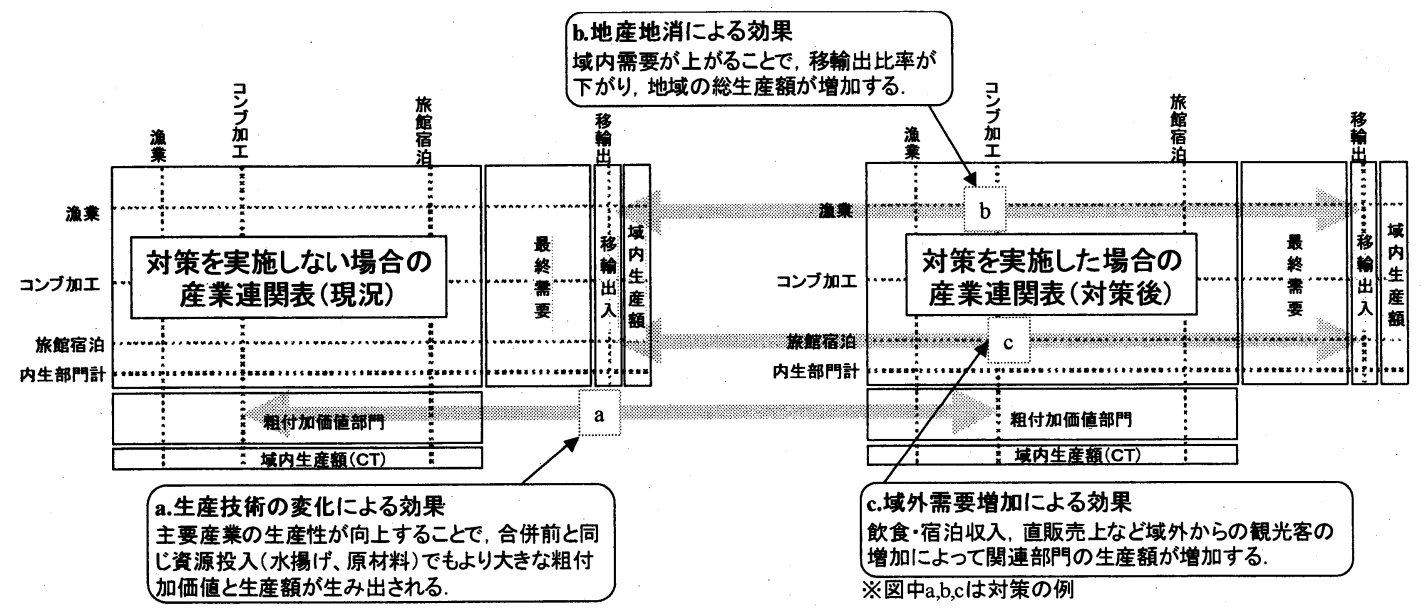

図一8 施策の効果と分析方法

（1）漁業や関連産業など水産業の生産性が向上するよう な対策によって，同じ資源の投入（水揚，原材料） でも大きな粗付加価值と生産額が生み出される.

(2) 水産物の地産地消などにより域内需要が向上するよ うな対策によって, 移輸出比率が減少し, 域内生産 額が増加する.

(3) 域外からの観光客の増加など域外需要が向上するよ うな対策によって, 飲食・宿泊・直販など水産関連 部門の生産額が増加する。

が考えられ, このような施策が実施される前と後での産 業構造を予測し, その差を施策による効果と考えること ができる。

\section{（2）効果の分析方法}

水産基盤整備の実施により期待できる効果は, 図一8 に示す方法で分析することができる.

水産基盤整備（以下，対策）により産業連関表自体が 変化し, その変化を効果として評価する方法で, その手 順は以下の通りである.

対策を実施しない場合の産業連関表を作成（現況）す る. 次に, 産業構造の課題を解決するために, 対策案(こ

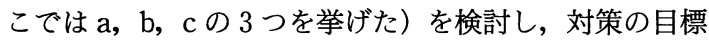
値を設定することで対策を奏施した場合の産業連関表 (対策後)を作成する. 効果分析は, 現況と対策後の産業
連関表における生産誘発額の比較, 雇用者所得の変化と 二次波及額の比較, 移輸入を考慮した逆行列係数の比較 （列和）などで算出できる.

\section{7.おわりに}

産業構造の変化を生む水産基盤整備, 市町村合併後の 対策を考える場合には，その漁村や地域が将来の明確な ビジョンを持ち, 既存産業間の連携, 観光と既存産業と の関連などを具体的に描くことが必要である.

つまり産業連関表上では，付加価值を付ける，中間投 入を減少させる, 移輸入を減らすなど, 産業構造の変化 を具体的に考えることが必要である．このことは，漁村 の産業連関表をつくる際に新たに部門を追加したり，既 存産業を細分類する場合にも必要な情報である.

漁村の産業連関表を作成する場合，漁業が主要な産業 であっても, 農業や観光業や商業など特徵的な産業が地 域に存在する場合, 産業構造の現況を現地で調査する方 法を検討する必要がある.

\section{参考 文 献}

土居英二・浅利一郎・中野親徳 (1996)：はじめよう地域産業連 関分析, 日本評論社, $268 \mathrm{p}$. 